\title{
Dietary Fiber Intake (Supplemental or Dietary Pattern Rich in Fiber) and Diabetic Kidney Disease: A Systematic Review of Clinical Trials
}

\author{
Cláudia Mesquita de Carvalho *(D), Luiza Azevedo Gross, Mirela Jobim de Azevedo ${ }^{\dagger}$ and \\ Luciana Verçoza Viana \\ Endocrine Division, Hospital de Clínicas de Porto Alegre, Universidade Federal do Rio Grande do Sul. Rua \\ Ramiro Barcelos 2350, Prédio 12, $4^{\circ}$ andar, Porto Alegre-RS 90035-003, Brazil; \\ luizaazevedogross@gmail.com (L.A.G.); vercoza@yahoo.com (L.V.V.) \\ * Correspondence: claudiamcarv@gmail.com; Tel.: +55-51-3359-8127 \\ + In Memoriam: Professor of Medicine, Endocrine Division, who deceased before publication of this work. \\ Her expertise was crucial for the design and conduct of this study.
}

Received: 3 January 2019; Accepted: 30 January 2019; Published: 6 February 2019

\begin{abstract}
Fiber intake is associated with better glycemic control being an important non-pharmacological treatment for diabetes (DM). We hypothesize that a dietary fiber intake can bring benefits to diabetic kidney disease (DKD), improving renal outcomes. This systematic review aimed to evaluate the effect of dietary fiber (supplemental or dietary pattern rich in fiber) on DKD. We searched six databases to identify clinical trials that reported fiber intake and renal outcomes (albuminuria, proteinuria, estimated glomerular filtration rate (eGFR) dialysis) in patients with DM. From 1814 studies, 48 papers were fully evaluated. In the end, seven trials (161 patients, aged 58.3 years, $49 \%$ females) were included. The studies were organized into three categories (vegetarian, Dietary Approaches to Stop Hypertension (DASH) diet, and fiber supplement), two evaluated supplements and five dietary patterns. Vegetarian diet reduced albuminuria in three trials, two in patients with type $1 \mathrm{DM}$ and one in patients with type 2 $\mathrm{DM}$; and one study demonstrated a change in the eGFR in type $1 \mathrm{DM}$. The individual quality of the studies was low/uncertain. A vegetarian dietary pattern may have a beneficial effect on these renal outcomes. However, the individual effect of the intake of fiber on DKD not was possible to be evaluated.
\end{abstract}

Keywords: vegetarian diet; diabetic nephropathy; albuminuria; glomerular filtration rate; systematic review

\section{Introduction}

Diabetes Mellitus (DM) is a growing worldwide epidemic. Approximately, 425 million adults are affected by this chronic disease [1]. Most of the financial burden of DM is related to management of its complications, and chronic kidney disease (CKD) is the most expensive and debilitating [2]. Cardiovascular disease (CVD) is a frequent cause of mortality in patients with type 2 DM [3], and it is well established that CKD is a risk factor for CVD [4]. Among patients with type $2 \mathrm{DM}$ and coronary artery disease, mortality rates were progressively higher in patients with mild and moderate CKD compared with patients with preserved estimated glomerular filtration rate (eGFR) [5].

Nutritional gaps in the knowledge of dietary management of DKD include amount and quality of carbohydrates, protein, and fat intake [6]. It is known that fiber intake is associated with better glycemic control [7] and cardiovascular risk reduction [8]. Table 1 shows an overview of dietary fiber recommendations. The American Diabetes Association (ADA) [9] recommends that patients with DM should consume at least 14 grams of fiber for each 1000 kcals daily and it suggests that carbohydrate intake from vegetables, fruits, legumes, and whole grains, with an emphasis on foods 
higher in fiber and lower in glycemic load, is preferred over other sources of sugar [10]. The American Heart Association (AHA) also endorses healthy dietary patterns rich in fiber to prevent CVD, such as Dietary Approaches to Stop Hypertension (DASH) and Mediterranean diets [11]. In its latest edition, Dietary Guidelines for Americans [12] reinforced the idea of fiber consumption through specific foods and patterns.

Table 1. Characteristics of dietary patterns and fiber recommendations.

\begin{tabular}{|c|c|c|}
\hline $\begin{array}{c}\text { Dietary Patterns/ } \\
\text { Guidelines Recommendations }\end{array}$ & Main Foods & Nutrients Characteristics \\
\hline DASH diet $1,2,4$ & $\begin{array}{l}\text { Includes vegetables, fruits, whole grains, fat-free } \\
\text { or low-fat dairy products, fish, poultry, beans, } \\
\text { nuts, and vegetable oils; }<25 \% \text { dietary intake } \\
\text { from fat; low in sweets, sugar-sweetened } \\
\text { beverages, and tropical oils. }\end{array}$ & $\begin{array}{l}\text { Low in saturated fats and cholesterol } \\
\text { Rich in fiber } \\
\text { Rich in protein }\end{array}$ \\
\hline Vegetarian diet $2,3,4$ & $\begin{array}{c}\text { Includes whole grains, vegetables, fruits, } \\
\text { legumes, nuts, seeds, soy and, if desired, dairy } \\
\text { products, and eggs. } \\
\text { Does not include meat, fowl or seafood, or } \\
\text { products containing those foods. }\end{array}$ & $\begin{array}{l}\text { Rich in fiber } \\
\text { Rich in } n-6 \text { fatty acids } \\
\text { Rich in vegetable protein }\end{array}$ \\
\hline Mediterranean diet $1,2,4$ & $\begin{array}{l}\text { Includes fruits, vegetables, whole grains, beans, } \\
\text { nuts, seeds, seafood, olive oil; low to moderate } \\
\text { amounts of poultry, and dairy products, with } \\
\text { little red meat; low to moderate wine } \\
\text { consumption (optional). }\end{array}$ & $\begin{array}{l}\text { Rich in fiber } \\
\text { Rich in monounsaturated and } \\
\text { polyunsaturated fat }\end{array}$ \\
\hline Guidelines recommendations & \multicolumn{2}{|c|}{$\begin{array}{c}2 \text { American Guideline: } 14 \mathrm{~g} / 1000 \mathrm{kcal} \\
{ }^{5} \text { European Guideline: } 25 \mathrm{~g} / \text { day } \\
{ }^{4} \text { ADA: } 14 \mathrm{~g} / 1000 \text { kcal or } 25 \mathrm{~g} / \text { day women, } 38 \mathrm{~g} / \text { day men } \\
{ }^{6} \mathrm{KDOQI} /{ }^{7} \text { KDIGO: no specific recommendation }\end{array}$} \\
\hline
\end{tabular}

$\mathrm{ADA}=$ American Diabetes Association; AHA = American Heart Association; KDOQI $=$ Kidney Disease Outcomes Quality Initiative; KDIGO = Kidney Disease Outcomes; Quality Initiative. ${ }^{1}$ American Heart Association-Guideline on Lifestyle Management to Reduce Cardiovascular Risk, 2013; ${ }^{2}$ Dietary Guidelines for Americans, $2015 ;{ }^{3}$ Position of the American Dietetic Association: Vegetarian Diets, 2015; ${ }^{4}$ American Diabetes Association, 2014/2018; ${ }^{5}$ Scientific Opinion on Dietary Reference Values for carbohydrates and dietary fiber, 2010; ${ }^{6}$ KDOQI-Chronic Kidney Disease Evidence-Based Nutrition Practice Guideline, $2010 ;{ }^{7}$ Diabetic Kidney Disease-A clinical update from Kidney Disease: KDIGO.

There is no precise recommendation about fiber intake or dietary patterns rich in fiber for patients with CKD $[6,13,14]$. Since the effect of dietary fiber on renal outcomes is not well established, and dietary fiber appears to be an important non-pharmacological treatment for DM and CVD, it is necessary to better understand and further investigate its effects on diabetic kidney disease (DKD). We hypothesize that a dietary fiber intake can bring benefits to DKD, through improve renal outcomes. Therefore, this systematic review aimed to evaluate the effect of dietary fiber (supplemental or dietary pattern rich in fiber) on DKD.

\section{Materials and Methods}

This systematic review was carried out using a protocol constructed according to the Cochrane Handbook recommendations [15], and it was reported in accordance with the Preferred Reporting Items for Systematic Reviews and Meta-Analyses (PRISMA) statement [16] (PROSPERO CRD42017072535).

\subsection{Data Sources and Searches}

We searched databases from Medline, Embase, ClinicalTrials.gov register, Scopus, Web of Science, and Cochrane databases to identify interventional clinical trials that reported dietary fiber intake (supplemental or dietary pattern rich in fiber) and renal outcomes (albuminuria, proteinuria, eGFR, and dialysis) in patients with DM, up to January 2018.

The initial search comprised the terms diabetes, dietary fiber, diabetic nephropathy, albuminuria, proteinuria, diabetic kidney disease, eGFR, renal replacement therapy, kidney failure chronic, and 
related entry terms. The complete Medline search strategy is presented in Appendix A, available in the Supporting Material for this article online. All potentially eligible studies were reviewed, regardless of the primary outcome or language.

\subsection{Study Selection}

Only interventional clinical trials conducted on patients with diabetes (type 1 or type 2 DM) with at least one high fiber group were included in the present review. Dietary fiber intake (supplemental or dietary pattern rich in fiber) was compared with conventional or low-fiber diets. Dietary intervention must have lasted at least four weeks. We excluded studies with non-clinical trials design (cohort, cross-sectional, case-control, and review studies), with the same dietary intervention in all studied groups, without dietary information, or without data about renal outcomes.

\subsection{Data Extraction and Quality Assessment}

All citations retrieved from electronic databases were imported into the EndNote Program. Two reviewers (CMC, LAG) independently analyzed the titles and abstracts of every paper retrieved from the literature search to identify potentially eligible studies. The full text of the remaining papers was obtained for further examination. Disagreements were solved by a third reviewer (LVV).

Data of included studies were independently extracted by the same two reviewers using a standardized form. Extracted data included: first author's name, year of publication, sample size, study design, trial duration, general characteristics of participants (the type of DM, age, gender, body mass index, $\mathrm{HbA1c}$, hypertension or blood pressure), intervention characteristics and outcomes of interest. A detailed description of the type of diet (actual intake or prescribed diet), total energy, macronutrients, and fiber content was documented for interventions and comparators.

In this review, we used renal outcomes definitions provided by authors of the included studies. In general, DKD is diagnosed based on the persistence of albuminuria and/or reduced eGFR in the absence of signs or symptoms of other primary causes of kidney damage [17]. End-of-study and baseline means or statistical dispersion for outcomes were extracted.

Methodological quality of studies was measured according to the Cochrane Collaboration's Handbook [15]. Biases were classified into six domains: selection, performance, detection, attrition, reporting, and other $[15,18]$. The "other" chosen domain was the assessment of dietary compliance. The risk of bias was independently analyzed by two reviewers (CMC, LAG) for each domain, and was classified as high, low, or unclear. Regarding dietary compliance, the risk was classified as "low" if the study described the method of a dietary adherence. The performance domain (blinding of participants and personnel) was not possible to evaluate in studies that have dietary intervention (dietary pattern).

\section{Results}

\subsection{Literature Search}

We identified 1814 studies in database searches. Of them, 1766 were excluded based on title and abstract, leaving 48 articles for further full-text evaluation. We excluded 41 studies (Appendix B), mainly due to lack of dietary or renal outcomes information, non-clinical trials design or only abstract available. As a result, seven interventional clinical trials were included in the current systematic review (Figure 1). 

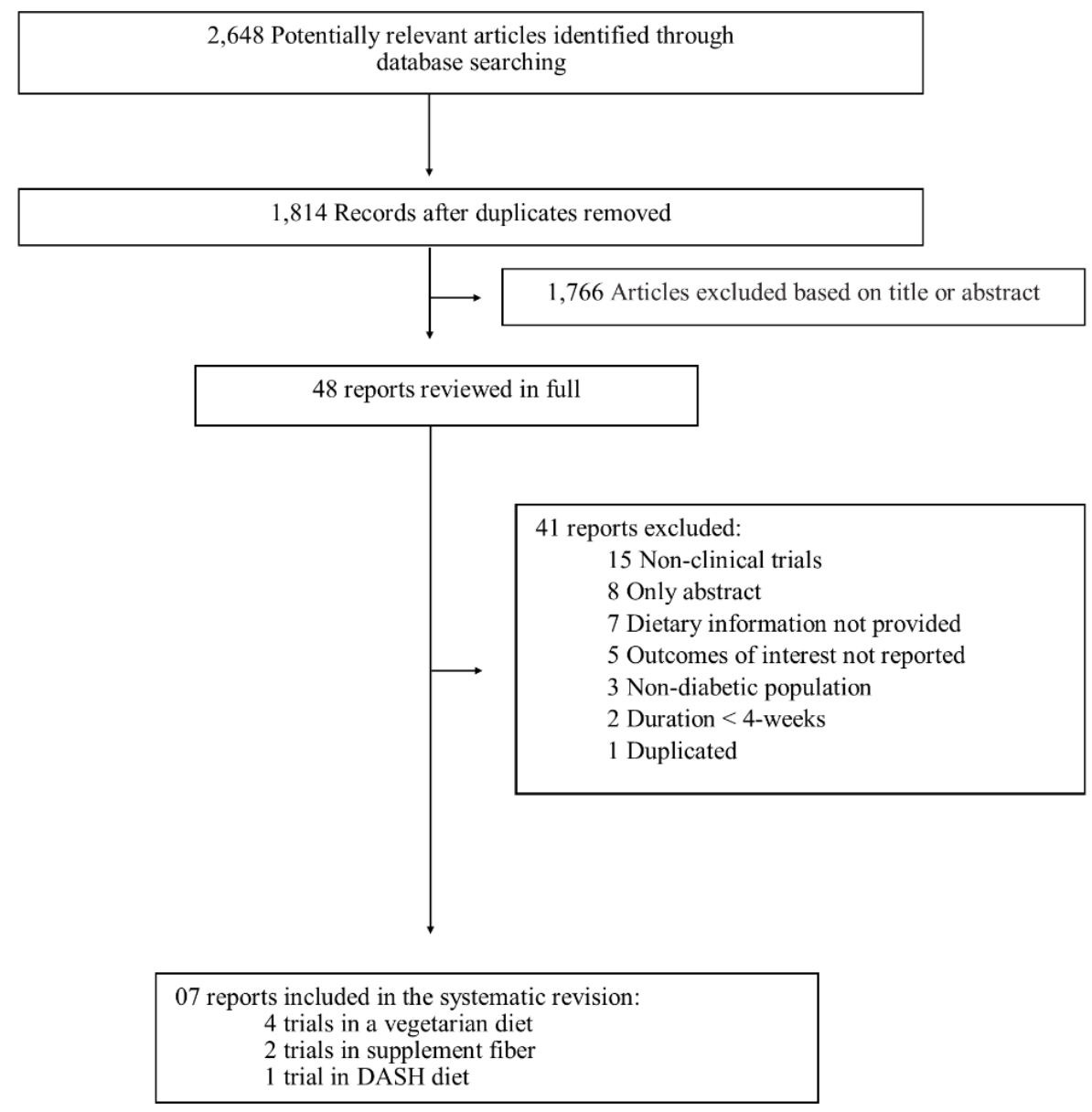

Figure 1. Flow diagram of the literature search to identify clinical trials evaluating the effect of dietary fiber on renal outcomes (albuminuria, eGFR) of patients with diabetes.

\subsection{Study Characteristics}

The seven interventional clinical trials comprised 161 patients with DM, age from 20 to 74 years (mean 58.3 years) and $49 \%$ females. HbA1c was reported in six studies (range 6.9-8.7\%). Good glycemic control, defined as $\mathrm{HbA1c}$ below $7 \%$ was achieved in two trials. Three trials had renal outcomes as a primary outcome [19-21], and only one study included patients with established renal disease (macroalbuminuria) [19]. All trials included few patients (range 8-49), had a small duration of the intervention (four to twelve weeks), and most studies were conducted in Brazil [19,22,23]. Four trials had a parallel design [22-25], and three showed a crossover design [19-21]. Two studies included patients with type 1 DM $[20,21]$. Dialysis and proteinuria were not reported in any included studies. Two studies $[23,24]$ did not describe eGFR, one study did not report albuminuria [25], and one study reported fractional albumin clearance [21]. Table 2 shows the complete description of the included trials. 
Table 2. Characteristics of the studies evaluating the effect of fiber intake on renal outcomes (albuminuria and eGFR) in patients with diabetes.

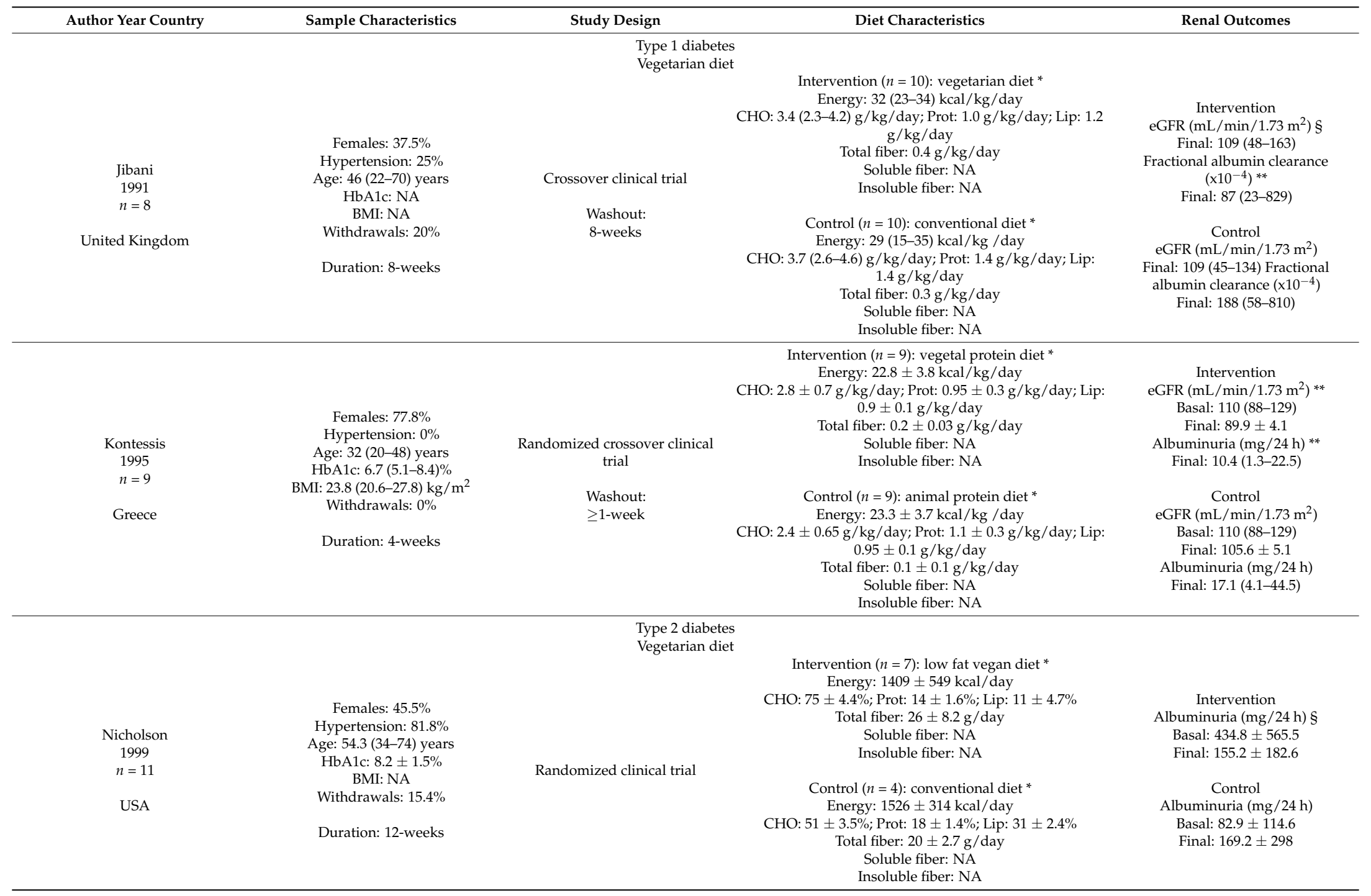


Table 2. Cont.

\begin{tabular}{|c|c|c|c|c|}
\hline Author Year Country & Sample Characteristics & Study Design & Diet Characteristics & Renal Outcomes \\
\hline \multirow{7}{*}{$\begin{array}{c}\text { Mello } \\
2006 \\
n=17\end{array}$} & & \multirow{7}{*}{$\begin{array}{c}\text { Randomized crossover clinical } \\
\text { trial }\end{array}$} & Intervention $(n=17)$ : lactovegetarian diet * & \\
\hline & & & Energy: $1634 \pm 451 \mathrm{kcal} / \mathrm{day}$ & Intervention \\
\hline & Females: $17.6 \%$ & & CHO: $58.7 \pm 6.8 \%$; Prot: $11.6 \pm 1.5 \%$; Lip: $29.5 \pm 6.8 \%$ & $\operatorname{eGFR}\left(\mathrm{mL} / \mathrm{min} / 1.73 \mathrm{~m}^{2}\right) \S$ \\
\hline & $\begin{array}{l}\text { Females: } 17.6 \% \\
\text { Hypertension. } 47 \%\end{array}$ & & Total fiber: $27 \pm 8.1 \mathrm{~g} /$ day & Final: $81.9 \pm 25.3$ \\
\hline & $\begin{array}{l}\text { Hypertension: } 47 \% \\
\text { Age: } 59+11 \text { vears }\end{array}$ & & Soluble fiber: NA & Albuminuria $(\mathrm{mg} / 24 \mathrm{~h}) * *$ \\
\hline & $\begin{array}{l}\text { Age: } 59 \pm 11 \text { years } \\
\text { HbA1c: } 7.6 \pm 2.6 \%\end{array}$ & & Insoluble fiber: NA & Final: 332.5 (111.1-1449) \\
\hline & BMI: $26.2 \pm 2.6 \mathrm{~kg} / \mathrm{m}^{2}$ & & & \\
\hline \multirow{4}{*}{ Brazil } & Withdrawals: $57.5 \%$ & \multirow{4}{*}{$\begin{array}{l}\text { Washout: } \\
\text { 4-weeks }\end{array}$} & $\begin{array}{l}\text { Control }(n=17): \text { usual diet * } \\
\text { Energy: } 1901 \pm 480 \mathrm{kcal} / \text { day }\end{array}$ & $\begin{array}{l}\text { Control } \\
\text { eGFR }\left(\mathrm{mL} / \mathrm{min} / 1.73 \mathrm{~m}^{2}\right)\end{array}$ \\
\hline & Dumotion A woole & & CHO: $46.9 \pm 6.7 \%$; Prot: $21.9 \pm 3.4 \%$; Lip: $30.8 \pm 6.3 \%$ & Final: $81.8 \pm 22.2$ \\
\hline & Duration: 4-weeks & & Total fiber: $20 \pm 7.5 \mathrm{~g} /$ day & Albuminuria (mg/24 h) \\
\hline & & & Soluble fiber: NA & Final: $453.6(324.4-1774.4)$ \\
\hline \multirow{10}{*}{$\begin{array}{c}\text { Dall'Alba } \\
2013 \\
n=44\end{array}$} & & \multirow{16}{*}{ Randomized clinical trial } & Insoluble fiber: NA & \\
\hline & & & Intervention ( $n=23)$ : $10 \mathrm{~g}$ guar gum supplement * & Intervention \\
\hline & & & Energy: $1700 \pm 439 \mathrm{kcal} /$ day & $\operatorname{eGFR}\left(\mathrm{mL} / \mathrm{min} / 1.73 \mathrm{~m}^{2}\right) \S$ \\
\hline & & & CHO: $184.2 \pm 28.1 \mathrm{~g} /$ day; Prot: $81.5 \pm 15.4$ g/day; Lip: & Basal: $84.8 \pm 16.6$ \\
\hline & & & $61.5 \pm 10.2 \mathrm{~g} /$ day & Final: $85 \pm 16.2$ \\
\hline & $\begin{array}{l}\text { Females: } 38.6 \% \\
\text { Hor }\end{array}$ & & Total fiber: $24.3 \pm 5.4 \mathrm{~g} /$ day & Albuminuria $(\mathrm{mg} / 24 \mathrm{~h}) \ddagger$ \\
\hline & Hypertension: $93.2 \%$ & & Soluble fiber: $14.8 \pm 1.9 \mathrm{~g} /$ day & Basal: $6.8(3-17.5)$ \\
\hline & Age: $62 \pm 9.7$ years & & Insoluble fiber: $9.5 \pm 3.6 \mathrm{~g} / \mathrm{day}$ & Final: $6.2(3-9.5)$ \\
\hline & $\begin{array}{l}\text { HbAlc: } 6.9 \pm 0.8 \% \\
\text { BMI: } 29.8 \pm 3.7 \mathrm{~kg} / \mathrm{m}^{2}\end{array}$ & & & \\
\hline & Withdrawals: $4.3 \%$ & & Control $(n=21)$ : control group * & Control \\
\hline \multirow[t]{6}{*}{ Brazil } & & & Energy: $1553 \pm 371 \mathrm{kcal} /$ day & $\operatorname{eGFR}\left(\mathrm{mL} / \mathrm{min} / 1.73 \mathrm{~m}^{2}\right) \S$ \\
\hline & Duration: 6-weeks & & CHO: $191.9 \pm 27.3 \mathrm{~g} /$ day; Prot: $86.3 \pm 12$ g/day; Lip: 58.3 & Basal: $89.2 \pm 16.7$ \\
\hline & & & $\pm 12.8 \mathrm{~g} /$ day & Final: $89 \pm 17.4$ \\
\hline & & & Total fiber: $15.7 \pm 6.3 \mathrm{~g} /$ day & Albuminuria $(\mathrm{mg} / 24 \mathrm{~h}) \S$ \\
\hline & & & Soluble fiber: $5.2 \pm 1.9 \mathrm{~g} /$ day & Basal: $6.7(3-19.3)$ \\
\hline & & & Insoluble fiber: $10.5 \pm 4.7 \mathrm{~g} /$ day & Final: $7.6(3-15.8)$ \\
\hline \multirow{12}{*}{$\begin{array}{c}\text { Farhangi } \\
2016 \\
n=49\end{array}$} & & \multirow{12}{*}{ Randomized clinical trial } & Intervention $(n=27)$ : $10 \mathrm{~g}$ chicory inulin supplement & \\
\hline & & & Energy: NA & \\
\hline & Females. $100 \%$ & & CHO: NA; Prot: NA; Lip: NA & Intervention \\
\hline & & & Total fiber: NA & $\operatorname{eGFR}\left(\mathrm{mL} / \mathrm{min} / 1.73 \mathrm{~m}^{2}\right) \S$ \\
\hline & Hypertension: NA & & Soluble fiber: $10 \mathrm{~g} /$ day & Basal: $86.3 \pm 14$ \\
\hline & $\begin{array}{l}\text { Age: } 48.3 \pm 8.8 \text { years } \\
\text { HbA1c: } 8.3 \pm 0.9 \%\end{array}$ & & Insoluble fiber: NA & Final: $84.3 \pm 13.6$ \\
\hline & $\begin{array}{l}\text { HbA1c: } 8.3 \pm 0.9 \% \\
\text { BMI: } 30.8 \pm 3.9 \mathrm{~kg} / \mathrm{m}^{2}\end{array}$ & & & \\
\hline & Withdrawals: $9.3 \%$ & & Control $(n=22)$ : placebo & Control \\
\hline & Withdrawals: $9.3 \%$ & & Energy: NA & $\mathrm{eGFR}\left(\mathrm{mL} / \mathrm{min} / 1.73 \mathrm{~m}^{2}\right)$ \\
\hline & Duration: 2-months & & CHO: NA; Prot: NA; Lip: NA & Basal: $85.3 \pm 13.5$ \\
\hline & & & Total fiber: NA & Final: $82.1 \pm 16.1$ \\
\hline & & & $\begin{array}{l}\text { Soluble fiber: NA } \\
\text { Insoluble fiber: NA }\end{array}$ & \\
\hline
\end{tabular}


Table 2. Cont

\begin{tabular}{|c|c|c|c|c|}
\hline Author Year Country & Sample Characteristics & Study Design & Diet Characteristics & Renal Outcomes \\
\hline $\begin{array}{c}\text { Paula } \\
2015 \\
n=40 \\
\text { Brazil }\end{array}$ & $\begin{array}{c}\text { Females: } 55 \% \\
\text { Hypertension: } 100 \% \\
\text { Age: } 62.2 \pm 8.4 \text { years } \\
\text { HbA1c: } 8.7 \pm 1.8 \% \\
\text { BMI: } 29.4 \pm 3.4 \mathrm{~kg} / \mathrm{m}^{2} \\
\text { Withdrawals: } 0 \% \\
\text { Duration: } 4 \text {-weeks }\end{array}$ & Randomized clinical trial & $\begin{array}{c}\text { Intervention }(n=20): \text { DASH diet * } \\
\text { Energy: } 1585 \pm 321 \mathrm{kcal} / \text { day } \\
\text { CHO: } 47.1 \pm 7.3 \% \text { Prot: } 23.5 \pm 6.7 \% \text {; Lip: } 29.4 \pm 5.8 \% \\
\text { Total fiber: } 20.1 \pm 4.3 \mathrm{~g} / \text { day } \\
\text { Soluble fiber: } 6.1 \pm 2.1 \mathrm{~g} / \text { day } \\
\text { Insoluble fiber: } 12.9 \pm 2.9 \mathrm{~g} \text { /day } \\
\text { Control }(n=20): \text { ADA recommendations * } \\
\text { Energy: } 1752 \pm 299 \mathrm{kcal} / \text { day } \\
\text { CHO: } 39.3 \pm 9.9 \% \text {; Prot: } 23 \pm 3.8 \% \text {;ip: } 36.8 \pm 8 \% \\
\text { Total fiber: } 14.1 \pm 4.8 \mathrm{~g} / \text { day } \\
\text { Soluble fiber: } 4.7 \pm 2.1 \mathrm{~g} / \text { day } \\
\text { Insoluble fiber: } 11 \pm 5.3 \text { g/day }\end{array}$ & $\begin{array}{c}\text { Intervention } \\
\text { Albuminuria }(\mathrm{mg} / 24 \mathrm{~h}) \S \\
\text { Basal: } 41.6(22.1-185.8) \\
\text { Final: } 31.8(10.2-132.7) \ddagger \\
\text { Control } \\
\text { Albuminuria }(\mathrm{mg} / 24 \mathrm{~h}) \\
\text { Basal: } 43.5(18.5-194.4) \\
\text { Final: } 33.4(11.2-119.6)\end{array}$ \\
\hline
\end{tabular}

Abbreviators: ADA = American Diabetic Association; BMI = body mass index; kcal = kilocalories; $\mathrm{CHO}=$ carbohydrates; DASH = Dietary Approaches to Stop Hypertension; Egfr = estimated glomerular filtration rate; Lip = Lipids; NA = Not available; NS = Not significant; Prot $=$ Protein. * actual intake ** $p<0.05$ for the effect of diet between groups; $\ddagger p<0.05$ for the effect of diet within group; § Not significant. 
Didactically, the studies were organized into three sections by type of dietary intervention: "vegetarian diet" $(n=4)$ [19-21,24], "fiber supplement" $(n=2)$ [22,25], and "DASH diet" $(n=1)$ [23]. Most interventions were compared to usual diet. Mean fiber intake in the intervention was $24 \mathrm{~g} /$ day (range: $20-27 \mathrm{~g} /$ day) and $16 \mathrm{~g} /$ day (range: $14-20 \mathrm{~g} /$ day) in the control group. Given the wide heterogeneity among studies regarding the type and form of dietary interventions, as well as the assessed outcomes, and the small number of studies identified in the literature, we could not perform a meta-analysis of the extracted data. The following sections provide additional detail on the included studies, grouped by type of intervention.

\subsection{Vegetarian diet}

\subsubsection{Type $1 \mathrm{DM}$}

Two interventional clinical trials, including 17 adult patients (age 32 to 46 years), 59\% females, assessed the vegetarian diets compared to a usual diet in patients with type 1 DM [20,21]. The studies were conducted in Greece [20] and the United Kingdom [21]. The intervention period ranged from four to eight weeks, and both had crossover clinical trials. Total fiber intake was 0.2 to $0.4 \mathrm{~g} / \mathrm{kg} /$ day in the intervention versus 0.1 to $0.3 \mathrm{~g} / \mathrm{kg} /$ day in the control group.

In the study conducted by Kontessis et al. [20], diets were isocaloric and with the same quantity of protein, but the intervention group contained exclusively vegetable protein and a mean fiber intake of $0.2 \mathrm{~g} / \mathrm{kg} /$ day versus $0.1 \mathrm{~g} / \mathrm{kg} /$ day in the control group. eGRF and albuminuria were significantly lower for the intervention group.

In the study of Jibani et al. [21], the intervention consisted of a predominantly vegetarian diet, with animal protein fraction limited to approximately $30 \%$ of the total protein intake. Median actual fiber consumption was $0.4 \mathrm{~g} / \mathrm{kg} /$ day in the intervention versus $0.3 \mathrm{~g} / \mathrm{kg} /$ day in the control. There was no change in eGFR, but the fractional albumin clearance was significantly lower in the vegetarian group compared with the conventional diet.

\subsubsection{Type $2 \mathrm{DM}$}

We found two randomized clinical trials that assessed the effect of a vegetarian diet on patients with type 2 DM [19,24]. The studies were conducted in the United States [24] and Brazil [19], the sample size ranged from 11 to 17 patients, with a mean age of 57 years, $36 \%$ were females, and the study duration ranged from four to twelve weeks. In the interventions, patients ingested $26.5 \mathrm{~g}$ of total fiber versus $20 \mathrm{~g}$ in the control groups (conventional diets).

In the pilot trial of Nicholson et al. [24], the intervention consisted of a low-fat vegan diet compared to a conventional diet, and there was no difference in the albuminuria between groups. The study performed by Mello et al. [19] was a crossover trial that evaluated the effects of a lactovegetarian compared with a chicken based or usual diet. No difference was observed in the eGFR between the vegetarian and usual or chicken diet. However, lactovegetarian and chicken-based diets reduced albuminuria by the same amount compared with usual diet. The quantity of fiber was greater in the lactovegetarian group, but the protein intake was smaller in the lactovegetarian group compared with chicken and usual diets.

\subsection{Fiber Supplement}

Two randomized clinical trials conducted in patients with type $2 \mathrm{DM}$ used $10 \mathrm{~g}$ of a soluble fiber supplement (guar gum or inulin) [22,25]. The studies were conducted in Brazil [22] and Iran [25] and the sample size ranged from 40 to 49 patients with a mean age of 54.5 years, $71 \%$ females, and mostly obese patients (BMI: $30.3 \mathrm{~kg} / \mathrm{m}^{2}$ ). The intervention period ranged from six weeks to two months.

In the study of Dall'Alba et al. [22], total fiber intake was $24 \mathrm{~g} /$ day (10 g/day of guar gum supplement) compared with $16 \mathrm{~g} /$ day in the control taken for six weeks. There was no difference in the eGFR and albuminuria between groups. 
The study of Farhangi et al. [25] included only women, and the intervention group received a $10 \mathrm{~g} /$ day chicory inulin as supplemental fiber, and the control group received $10 \mathrm{~g} /$ day maltodextrin for two months. No information was available about total fiber intake. No changes in eGFR values had been observed.

\subsection{DASH Diet}

Only one study evaluated the benefit of DASH diet and physical activity for four weeks compared with a diet based on ADA recommendations in patients with type $2 \mathrm{DM}$ [23]. The study was conducted in Brazil and included 40 patients with DM and hypertension, mean age 62 years old, $55 \%$ females. The total fiber consumed in the intervention group was 20 versus $14 \mathrm{~g} /$ day in the control group. There were no differences in albuminuria between groups at the end-of-the study.

\subsection{Methodological Quality Assessment of Studies}

None of the included studies satisfied all areas established by the Cochrane Handbook [15]. In general, the quality of the studies was low or uncertain. The selection bias domain was not possible to be evaluated in one study, because it was a non-randomized clinical trial [21]. Three studies provided a detailed description about random sequence generation [22,23,25], while only one study described the method used for allocation concealment [25]. The blinding of participants was described in two studies (dietary fiber supplement) [22,25]. The intervention providers were blinded to the group assignment in only one study [25]. One study had a loss of follow-up greater than $20 \%$ in the run-in period $(\sim 57 \%)$. On reporting bias, one study presented the outcome eGFR without having previously described it in the registry [19]. All studies properly presented the item "diet or supplement adherence". Table 3 shows the complete assessment of the methodological quality of the included studies.

Table 3. Assessment of methodological quality or risk of bias item for each included study.

\begin{tabular}{|c|c|c|c|c|c|c|c|}
\hline & \multicolumn{2}{|c|}{ Selection Bias } & \multirow{2}{*}{$\begin{array}{c}\begin{array}{c}\text { Performance } \\
\text { Bias }\end{array} \\
\text { Blinding of } \\
\text { participant } \\
\text { and personnel }\end{array}$} & \multirow{2}{*}{$\begin{array}{c}\begin{array}{c}\text { Detection } \\
\text { Bias }\end{array} \\
\text { Blinding of } \\
\text { outcome } \\
\text { assessment }\end{array}$} & \multirow{2}{*}{$\begin{array}{c}\text { Attrition Bias } \\
\begin{array}{c}\text { Incomplete } \\
\text { outcome data }\end{array}\end{array}$} & \multirow{2}{*}{$\begin{array}{c}\text { Reporting } \\
\text { Bias }\end{array}$} & \multirow{2}{*}{$\begin{array}{c}\text { Other Bias } \\
\text { Diet/supplement } \\
\text { adherence }\end{array}$} \\
\hline & $\begin{array}{l}\text { Random } \\
\text { sequence } \\
\text { generation }\end{array}$ & $\begin{array}{l}\text { Allocation } \\
\text { Concealment }\end{array}$ & & & & & \\
\hline $\begin{array}{l}\text { Jibani, } \\
1991\end{array}$ & $\mathrm{NA}^{*}$ & $\mathrm{NA}^{*}$ & NA * & Uncertain & Low & Uncertain & Low \\
\hline $\begin{array}{l}\text { Kontessis, } \\
1995\end{array}$ & Uncertain & Uncertain & NA * & Uncertain & Uncertain & Uncertain & Low \\
\hline $\begin{array}{l}\text { Nicholson, } \\
1999\end{array}$ & Uncertain & Uncertain & $\mathrm{NA}^{*}$ & Uncertain & Low & Uncertain & Low \\
\hline $\begin{array}{l}\text { Mello, } \\
2006\end{array}$ & Uncertain & Uncertain & $\mathrm{NA}^{*}$ & Uncertain & High & Uncertain & Low \\
\hline $\begin{array}{l}\text { Dall'Alba, } \\
2013\end{array}$ & Low & Uncertain & High & Uncertain & Low & Low & Low \\
\hline $\begin{array}{l}\text { Paula, } \\
2015\end{array}$ & Low & Uncertain & $\mathrm{NA}^{*}$ & Uncertain & Low & Low & Low \\
\hline $\begin{array}{l}\text { Farhangi, } \\
2016\end{array}$ & Low & Low & Low & Low & Low & High & Low \\
\hline
\end{tabular}

Abbreviators: * NA = not applicable for this type of study. Adapted from Cochrane Collaboration's tool.4.

\section{Discussion}

Diet is the cornerstone treatment for patients with DM and as far as we know this is the first systematic review that attempts to shows benefits of a consumption of dietary fiber on renal outcomes in patients with DM. Among the seven included studies, only the vegetarian dietary pattern was associated with beneficial kidney outcomes: three studies showed a reduction of albuminuria (two conducted in patients with type $1 \mathrm{DM}$ and one in patients with type $2 \mathrm{DM}$ ) and one study demonstrated a change in the eGFR in patients with type $1 \mathrm{DM}$.

As we already know, the pathogenesis of diabetic nephropathy has complex mechanisms including the effect of high glucose, endothelial dysfunction inflammation, renin-angiotensin system 
activation, reactive oxygen species, increase of advanced glycation end-product, and glomerular hyperfiltration [26]. Dietary fiber plays an important role in glycemic control [7,27] and regardless of the source (food or supplements) fiber exhibits hypoglycemic actions in patients with type 2 DM [28,29]. Some studies have shown that good glycemic control reduces albuminuria [30-32] in patients with $\mathrm{DM}$ and dietary fiber intake was found to be associated with a reduced risk of albuminuria in a cross-sectional study [33]. Recently, a Japanese randomized clinical trial showed that a diet higher in fiber was able to improve endothelial function, possibly by a reduction of glucose excursions, in patients with type $2 \mathrm{DM}[34]$.

In the general population, consumption of fiber-rich foods can reduce serum creatinine levels $[35,36]$ and may increase eGFR in CKD patients without DM [36]. A prospective study showed that high fiber intake, mainly from legumes and vegetables, was related to lower incidence of CKD after six years of follow-up. For every additional $5 \mathrm{~g} /$ day of fiber intake, there was an $11 \%$ reduction in risk of CKD [37]. In fact, the precise effects of dietary fiber consumption on renal function are not well known, but healthy dietary patterns with high fiber are associated with lower mortality in people with kidney disease [38].

In our systematic review, a dietary pattern rich in fiber: Vegetarian diet was the only category associated with a reduction in albuminuria in both type 1 and type $2 \mathrm{DM}$ patients and reduction in eGFR in a group of patients with type $1 \mathrm{DM}$ and possible hyperfiltration. It is worth noting that protein intake was lower in two out of three of these studies. It has been suggested that plant-based proteins may exert beneficial effects on blood pressure, protein loss in urine, and GFR, and reduce renal tissue damage preventing the progression of CKD when compared to animal proteins [39]. It is difficult to isolate the effect of a single nutrient, in this case, dietary fiber from protein. A vegetarian dietary pattern is usually richer in fibers, but it is lower in animal protein, which may be more suitable for these patients and exert beneficial glomerular effects [40]. Higher eGFR has been demonstrated in patients with a normal renal function on an animal protein diet in comparison with a person on a vegetable-based diet [41,42].

Bioavailability of dietary proteins in plant-based diets is diverse. The content of phosphorus, amino acids types, and advanced glycation end products (AGEs) is distinguished in animal and plant diets. Plant-based sources of protein tend to have the less bioavailable form of phosphorus as phytate compared to organic phosphorus found in processed foods as well as in animal sources of protein. The mechanisms by which plant-based diets may reduce DKD progression may be related to the form of phosphorus, AGEs, a reduction in blood pressure by decreasing sodium, an increase in fiber leading to improved glycemic control, or from bioactive compounds in soy protein-based diets, such as isoflavones [43]. Additionally, dietary protein also delivers an increased acid load per nephron providing a non-hemodynamic mechanism promoting renal injury through the induction of endothelin and aldosterone in response to increased nephron ammonia generation. In the presence of proteinuria, increased dietary protein alters glomerular permselectivity, increasing urinary albumin loss [44].

In our review, no other dietary pattern had favorable effects on renal outcomes. DASH diet was not able to reduce eGFR or albuminuria in patients with type $2 \mathrm{DM}$ similar to the results of Jacobs et al. in patients without DM [45]. However, in two large, prospective, long-term studies, adherence to DASH diet was associated with protection against eGFR decline [46,47]. No clinical trial specifically designed to evaluate the effects of a Mediterranean diet in patients with DM was identified in our database search. In a recent cohort study, a Mediterranean dietary pattern was associated with a decreased risk of CKD in patients with and without DM [48]. A Mediterranean diet was too evaluated in a randomized clinical trial, PREDIMED (PREvencion con DIeta MEDiterranea) study. However, two subgroup analyses that evaluated only patients with type $2 \mathrm{DM}$, showed no difference in nephropathy between Mediterranean groups compared to a low-fat diet [49,50]. These studies were not included in this systematic review due to them not presenting the dietary fiber intake.

Limitations of our systematic review are the small number of studies, with a small sample size, few ethnic groups represented among the participants, and short follow-up time (no more than twelve 
weeks). This may limit the effect of any dietary intervention in renal outcomes, particularly because CKD is a slowly progressive disease. Many years may be necessary for the development of kidney damage. In fact, DKD was present in only one study in our systematic review [19]. Regarding the quality of the included studies, lack of description of trial characteristics made the quality analysis unclear in several domains. Fiber dietary intake in included studies was lower than recommended by most dietary guidelines ( $38 \mathrm{~g} /$ day for men and $25 \mathrm{~g} /$ day women) $[9,51,52]$. In addition, we could not establish an independent fiber effect on renal outcomes since most included studies evaluated eating patterns. On the other hand, dietary patterns seem to be more important than a single nutrient and offer a more practical application in public health promotion since it is easier for people to adopt dietary patterns instead of specific nutrients from their diets [53].

Evidence of benefits of dietary fiber on renal outcomes in patients with DM is still limited, and more precise indications of the amount, duration, and the type of fiber intake to achieve these goals are needed. Regrettably, we could not evaluate the individual effect of different fiber sources (legumes, vegetables, or fruits) on the outcomes. We know that all fibers are not the same and sources of fibers carry other nutrients (i.e., vitamins and minerals) that on their own already have positive effects on health. Available data extrapolated from the general population, show that fiber intake is likely protective against CKD progression and mortality [27,37,54], and every effort should be made to encourage higher fiber intake in the CKD population. Unfortunately, we could not reach a definitive conclusion regarding the beneficial effect of fiber in DKD in our systematic review. Still, larger, longer, better design trials are needed to evaluate the effect of fiber on DKD.

A vegetarian dietary pattern may have a beneficial effect on these renal outcomes. However, the individual effect of the intake of fiber on DKD was not possible to be evaluated on our systematic review. New randomized trials are needed to reach a definitive conclusion.

Author Contributions: C.M.C. and L.A.G. collected the data. C.M.C. wrote the first draft with contributions from L.V.V. L.V.V. participated in drafting the article or revising it critically for important intellectual content and gave final approval of the version to be submitted and any revised version. M.J.A. made substantial contributions to conception and design. C.M.C., L.A.G. and L.V.V. reviewed and commented on subsequent drafts of the manuscript.

Acknowledgments: Sources of Support: This study was supported by Coordenação de Aperfeiçoamento de Pessoal de Nivel Superior (CAPES) and Fundo de Incentivo à Pesquisa (FIPE)-Hospital de Clínicas de Porto Alegre. C.M.C. was the recipient of a scholarship from CAPES.

Conflicts of Interest: The authors declare no conflict of interest.

\section{Appendix A MEDLINE Search Strategy for the Systematic Review}

(((("Diabetes Mellitus" [Mesh] OR (Diabetes Mellitus) OR “Diet, Diabetic” [Mesh] OR (Diet, Diabetic) OR (Diabetic Diets) OR (Diets, Diabetic) OR (Diabetic Diet) OR "Diabetes Mellitus, Type 2" [Mesh] OR (Diabetes Mellitus, Type 2) OR (Noninsulin-Dependent Diabetes Mellitus) OR (Type 2 Diabetes Mellitus) OR (Diabetes Mellitus, Type II) OR (Stable Diabetes Mellitus) OR (Diabetes Mellitus, Stable) OR (Slow-Onset Diabetes Mellitus) OR (Diabetes Mellitus, Slow Onset) OR (Diabetes Mellitus, Slow-Onset) OR (Diabetes Mellitus, Noninsulin Dependent) OR (Non-Insulin-Dependent Diabetes Mellitus) OR (Diabetes Mellitus, Non-Insulin-Dependent) OR (Diabetes Mellitus, Non Insulin Dependent) OR (Maturity-Onset Diabetes) OR (Diabetes Mellitus, Adult-Onset) OR (Diabetes Mellitus, Noninsulin-Dependent) OR (Adult-Onset Diabetes Mellitus) OR (Diabetes Mellitus, Adult Onset) OR (NIDDM) OR (Diabetes Mellitus, Maturity Onset) OR (Diabetes Mellitus, Maturity-Onset) OR (Diabetes Mellitus, Ketosis-Resistant) OR (Diabetes Mellitus, Ketosis Resistant) OR (Ketosis-Resistant Diabetes Mellitus) OR (Type II DM) OR (Type 2 DM) OR "Diabetes Mellitus, Type 1" [Mesh] OR (Diabetes Mellitus, Type 1) OR (Diabetes Mellitus, Brittle) OR (Brittle Diabetes Mellitus) OR (Diabetes Mellitus, Insulin-Dependent) OR (Diabetes Mellitus, Insulin Dependent) OR (Insulin-Dependent Diabetes Mellitus) OR (Diabetes Mellitus, Juvenile-Onset) OR (Diabetes Mellitus, Juvenile Onset) OR (Juvenile-Onset Diabetes Mellitus) OR (Diabetes Mellitus, Ketosis-Prone) OR (Diabetes Mellitus, Ketosis Prone) OR (Ketosis-Prone Diabetes Mellitus) OR 
(Juvenile-Onset Diabetes) OR (Diabetes, Juvenile-Onset) OR (Juvenile Onset Diabetes) OR (Diabetes Mellitus, Type I) OR (Diabetes Mellitus, Sudden-Onset) OR (Diabetes Mellitus, Sudden Onset) OR (Diabetes Mellitus, Sudden Onset) OR (Sudden-Onset Diabetes Mellitus) OR (Type 1 Diabetes Mellitus) OR (Diabetes Mellitus, Insulin-Dependent, 1) OR (Insulin-Dependent Diabetes Mellitus 1) OR (Insulin Dependent Diabetes Mellitus 1) OR (Type 1 Diabetes) OR (Diabetes, Type 1) OR (IDDM) OR (Diabetes, Autoimmune) OR (Autoimmune Diabetes)))) AND ("Dietary Fiber" [Mesh] OR (Dietary Fiber) OR (Fiber, Dietary) OR (Dietary Fibers) OR (Fibers, Dietary) OR (Roughage) OR (Roughages) OR (Wheat Bran) OR (Bran, Wheat) OR (Brans, Wheat) OR (Wheat Brans) OR "Whole Grains" [Mesh] OR (Whole Grains) OR (Grain, Whole) OR (Grains, Whole) OR (Whole Grain) OR (Whole Grain Cereals) OR (Cereal, Whole Grain) OR (Cereals, Whole Grain) OR (Grain Cereal, Whole) OR (Grain Cereals, Whole) OR (Whole Grain Cereal) OR (Cereal fiber) OR "Plants, Edible" [Mesh] OR (Plants, Edible) OR (Edible Plant) OR (Edible Plants) OR (Plant, Edible) OR (Food Plants) OR (Food Plant) OR (Plant, Food) OR (Plants, Food) OR "Vegetables" [Mesh] OR (Vegetables) OR (Vegetable) OR "Fruit" [Mesh] OR (Fruit) OR (Fruits) OR (Plant Aril) OR (Arils, Plant) OR (Aril, Plant) OR (Plant Arils) OR (Fiber) OR (Soluble fiber) OR (Total fiber) OR (Insoluble fiber) OR “Diet, Vegetarian"[Mesh] OR (Diet, Vegetarian) OR (Diets, Vegetarian) OR (Vegetarian Diets) OR (Vegetarian Diet) OR (Vegetarianism) OR “Diet, Vegan" [Mesh] OR (Diet, Vegan) OR (Diets, Vegan) OR (Vegan Diets) OR (Vegan Diet) OR (Veganism) OR (Diet, Dash) OR (Diets, Dash) OR (Dash Diet) OR (Dash Diets) OR (Dash) OR (Dietary Approaches to Stop Hypertension) OR “Diet, Mediterranean"[Mesh] OR (Diet, Mediterranean) OR (Mediterranean Diet) OR (Diets, Mediterranean) OR “Inulin"[Mesh] OR (Inulin) OR “Psyllium”[Mesh] OR (Psyllium) OR (Gum, Ispaghule) OR (Ispaghula) OR (Guar gum) OR (Gum guar)))) AND (("Diabetic Nephropathies" [Mesh] OR (Diabetic Nephropathies) OR (Nephropathies, Diabetic) OR (Nephropathy, Diabetic) OR (Diabetic Nephropathy) OR (Diabetic Kidney Disease) OR (Diabetic Kidney Diseases) OR (Kidney Disease, Diabetic) OR (Kidney Diseases, Diabetic) OR (Diabetic Glomerulosclerosis) OR (Kimmelstiel-Wilson Syndrome) OR (Kimmelstiel Wilson Syndrome) OR (Syndrome, Kimmelstiel-Wilson) OR (Kimmelstiel-Wilson Disease) OR (Kimmelstiel Wilson Disease) OR (Nodular Glomerulosclerosis) OR (Glomerulosclerosis, Nodular) OR (Glomerulosclerosis, Diabetic) OR "Albuminuria"[Mesh] OR (Albuminuria) OR (Albuminurias) OR "Proteinuria" [Mesh] OR (Proteinuria) OR (Proteinurias) OR (Microalbuminuria) OR (Macroalbuminuria) OR (Diabetic Renal Disease) OR (Increased urinary albumin excretion) OR “Glomerular Filtration Rate"[Mesh] OR (Glomerular Filtration Rate) OR (Filtration Rate, Glomerular) OR (Filtration Rates, Glomerular) OR (Glomerular Filtration Rates) OR (Rate, Glomerular Filtration) OR (Rates, Glomerular Filtration) OR (Chronic Kidney Disease) OR (Renal Replacement Therapy[Mesh]) OR (Renal Replacement Therapy) OR “Dialysis"[Mesh] OR (Dialysis) OR (Dialyses) OR “Renal Dialysis"[Mesh] OR (Renal Dialysis) OR (Hemodialysis) OR (Hemodialyses) OR "Kidney Failure, Chronic"[Mesh] OR (Kidney Failure, Chronic) OR (End-Stage Kidney Disease) OR (Disease, End-Stage Kidney) OR (End Stage Kidney Disease) OR (Kidney Disease, End-Stage) OR (Chronic Kidney Failure) OR (End-Stage Renal Disease) OR (Disease, End-Stage Renal) OR (End Stage Renal Disease) OR (Renal Disease, End-Stage) OR (Renal Disease, End Stage) OR (Renal Failure, End-Stage) OR (End-Stage Renal Failure) OR (Renal Failure, End Stage) OR (Renal Failure, Chronic) OR (Chronic Renal Failure) OR (ESRD) OR (ESKD) OR “Renal Insufficiency, Chronic"[Mesh] OR (Renal Insufficiency, Chronic) OR (Chronic Renal Insufficiencies) OR (Chronic Renal Insufficiencies) OR (Renal Insufficiencies, Chronic) OR (Chronic Renal Insufficiency) OR (Kidney Insufficiency, Chronic) OR (Chronic Kidney Insufficiency) OR (Chronic Kidney Insufficiencies) OR (Kidney Insufficiencies, Chronic) OR (Chronic Kidney Diseases) OR (Chronic Kidney Disease) OR (Disease, Chronic Kidney) OR (Diseases, Chronic Kidney) OR (Kidney Disease, Chronic) OR (Kidney Diseases, Chronic) OR (Chronic Renal Diseases) OR (Chronic Renal Disease) OR (Disease, Chronic Renal) OR (Diseases, Chronic Renal) OR (Renal Disease, Chronic) OR (Renal Diseases, Chronic))). 
Appendix B Excluded Studies of the Systematic Review $(n=41)$

\begin{tabular}{|c|c|c|c|}
\hline Author & Year & Periodic & Reasons to exclusion \\
\hline Paisey & 1984 & Diabetes Care & Non-clinical trials \\
\hline Parillo & 1984 & $\begin{array}{l}\text { Minerva } \\
\text { Endocrinologica }\end{array}$ & Duration $<4$-weeks \\
\hline Barsotti & 1987 & $\begin{array}{l}\text { Infusionstherapie und } \\
\text { Klinische Ernährung }\end{array}$ & Only abstract \\
\hline Parillo & 1988 & $\begin{array}{l}\text { American Journal of } \\
\text { Clinical Nutrition }\end{array}$ & Duration $<4$-weeks \\
\hline Barsotti & 1988 & $\begin{array}{l}\text { Contributions of } \\
\text { Nephrology }\end{array}$ & Only abstract \\
\hline Naumova & 1990 & Vŭtreshni Bolesti & Only abstract \\
\hline Barsotti & 1991 & $\begin{array}{c}\text { American Journal of } \\
\text { Nephrology }\end{array}$ & Non-diabetic population \\
\hline Metcalf & 1993 & Clinical Chemistry & Outcomes of interest not reported \\
\hline Hadfield & 1993 & Practical Diabetes & Non-clinical trials \\
\hline Oldrizzi & 1994 & $\begin{array}{l}\text { Journal of the American } \\
\text { Society of Neprhology }\end{array}$ & Dietary information not provided \\
\hline Citro & 1998 & $\begin{array}{c}\text { Minerva } \\
\text { Endocrinologica }\end{array}$ & Outcomes of interest not reported \\
\hline GSEDNu & 2006 & $\begin{array}{l}\text { Journal of Diabetes and } \\
\text { Complications }\end{array}$ & Non-clinical trials \\
\hline Brunori & 2007 & $\begin{array}{c}\text { American Journal of } \\
\text { Kidney Diseases }\end{array}$ & Non-diabetic population \\
\hline Cámara & 2008 & $\begin{array}{l}\text { Revista Espanhola de } \\
\text { Salud Publica }\end{array}$ & Outcomes of interest not reported \\
\hline Glover & 2009 & Food Hydrocolloids & Outcomes of interest not reported \\
\hline Teixeira & 2010 & Diabetes & Outcomes of interest not reported \\
\hline Gong & 2011 & Diabetologia & Dietary information not provided \\
\hline Lin & 2011 & $\begin{array}{c}\text { American Journal of } \\
\text { Kidney Diseases }\end{array}$ & Dietary information not provided \\
\hline Sun & 2011 & $\begin{array}{l}\text { Journal of Chinese } \\
\text { Clinical Medicine }\end{array}$ & Only abstract \\
\hline Reddy & 2012 & $\begin{array}{c}\text { Kidney Research Clinical } \\
\text { Practice }\end{array}$ & Non-clinical trials \\
\hline Dunkler & 2013 & JAMA Internal Medicine & Non-clinical trials \\
\hline Chang & 2013 & $\begin{array}{l}\text { American Journal of } \\
\text { Kidney Diseases }\end{array}$ & Non-clinical trials \\
\hline Tirosh & 2013 & Diabetes Care & Only abstract \\
\hline Dans & 2013 & $\begin{array}{l}\text { Phillipine Journal of } \\
\text { Internal med }\end{array}$ & Only abstract \\
\hline Khatri & 2014 & $\begin{array}{l}\text { Clinical Journal of the } \\
\text { American Society of } \\
\text { Nephrology }\end{array}$ & Non-clinical trials \\
\hline
\end{tabular}




\begin{tabular}{|c|c|c|c|}
\hline Author & Year & Periodic & Reasons to exclusion \\
\hline Hsu & 2014 & Clinical Nutrition & Non-clinical trials \\
\hline $\mathrm{Xu}$ & 2014 & $\begin{array}{l}\text { Clinical Journal of the } \\
\text { American Society of } \\
\text { Nephrology }\end{array}$ & Non-clinical trials \\
\hline Díaz-López & 2015 & Diabetes Care & Dietary information not provided \\
\hline Villarini & 2015 & Annali di Igiene & Non-diabetic population \\
\hline Lee & 2015 & $\begin{array}{c}\text { Nephrology Dialysis } \\
\text { Transplantation }\end{array}$ & Non-clinical trials \\
\hline Nazha & 2015 & $\begin{array}{l}\text { Nephrology Dialysis } \\
\text { Transplantation }\end{array}$ & Only abstract \\
\hline Rebholz & 2016 & $\begin{array}{c}\text { American Journal of } \\
\text { Kidney Diseases }\end{array}$ & Duplicated \\
\hline Dunkler & 2016 & $\begin{array}{c}\text { American Journal of } \\
\text { Kidney Diseases }\end{array}$ & Non-clinical trials \\
\hline Piccoli & 2016 & BMC Nephrology & Dietary information not provided \\
\hline Ashgari & 2016 & Hypertension Research & Non-clinical trials \\
\hline Hirahatake & 2016 & Circulation & Dietary information not provided \\
\hline Rebhold & 2016 & $\begin{array}{c}\text { American Journal of } \\
\text { Nephrology }\end{array}$ & Non-clinical trials \\
\hline Mejia & 2016 & The FASEB Journal & Only abstract \\
\hline Ashgari & 2017 & $\begin{array}{l}\text { Nephrology, Dialysis, } \\
\text { Transplantation }\end{array}$ & Non-clinical trials \\
\hline Horikawa & 2017 & Nutrients & Non-clinical trials \\
\hline Duncan & 2017 & $\begin{array}{c}\text { Diabetology and } \\
\text { Metabolic Syndrome }\end{array}$ & Dietary information not provided \\
\hline
\end{tabular}

\section{References}

1. International Diabetes Federation. IDF Diabetes Atlas, 8th ed.; International Diabetes Federation: Brussels, Belgium, 2017.

2. Slabaugh, S.L.; Curtis, B.H.; Clore, G.; Fu, H.; Schuster, D.P. Factors associated with increased healthcare costs in Medicare Advantage patients with type 2 diabetes enrolled in a large representative health insurance plan in the US. J. Med. Econ. 2015, 18, 106-112. [CrossRef] [PubMed]

3. Lupsa, B.C.; Inzucchi, S.E. Diabetes medications and cardiovascular disease: At long last progress. Curr. Opin. Endocrinol. Diabetes Obes. 2018, 25, 87-93. [CrossRef] [PubMed]

4. Sarnak, M.J.; Levey, A.S.; Schoolwerth, A.C.; Coresh, J.; Culleton, B.; Hamm, L.L.; McCullough, P.A.; Kasiske, B.L.; Kelepouris, E.; Klag, M.J.; et al. Kidney disease as a risk factor for development of cardiovascular disease: A statement from the American Heart Association Councils on Kidney in Cardiovascular Disease, High Blood Pressure Research, Clinical Cardiology, and Epidemiology and Prevention. Circulation 2003, 108, 2154-2169. [CrossRef] [PubMed]

5. Lima, E.G.; Hueb, W.; Gersh, B.J.; Rezende, P.C.; Garzillo, C.L.; Favarato, D.; Hueb, A.C.; Rahmi Garcia, R.M.; Franchini Ramires, J.A.; Filho, R.K. Impact of Chronic Kidney Disease on Long-Term Outcomes in Type 2 Diabetic Patients With Coronary Artery Disease on Surgical, Angioplasty, or Medical Treatment. Ann. Thorac. Surg. 2016, 101, 1735-1744. [CrossRef] [PubMed]

6. Ko, G.J.; Kalantar-Zadeh, K.; Goldstein-Fuchs, J.; Rhee, C.M. Dietary Approaches in the Management of Diabetic Patients with Kidney Disease. Nutrients 2017, 9, 824. [CrossRef] [PubMed] 
7. Silva, F.M.; Kramer, C.K.; de Almeida, J.C.; Steemburgo, T.; Gross, J.L.; Azevedo, M.J. Fiber intake and glycemic control in patients with type 2 diabetes mellitus: A systematic review with meta-analysis of randomized controlled trials. Nutr. Rev. 2013, 71, 790-801. [CrossRef] [PubMed]

8. McRae, M.P. Dietary Fiber Is Beneficial for the Prevention of Cardiovascular Disease: An Umbrella Review of Meta-analyses. J. Chiropr. Med. 2017, 16, 289-299. [CrossRef]

9. Evert, A.B.; Boucher, J.L.; Cypress, M.; Dunbar, S.A.; Franz, M.J.; Mayer-Davis, E.J.; Neumiller, J.J.; Nwankwo, R.; Verdi, C.L.; Urbanski, P.; et al. Nutrition therapy recommendations for the management of adults with diabetes. Diabetes Care 2014, 37 (Suppl. 1), S120-S143. [CrossRef]

10. American Diabetes Association. 4. Lifestyle Management: Standards of Medical Care in Diabetes-2018. Diabetes Care 2018, 41 (Suppl. 1), S38-S50. [CrossRef]

11. Eckel, R.H.; Jakicic, J.M.; Ard, J.D.; de Jesus, J.M.; Houston Miller, N.; Hubbard, V.S.; Lee, I.M.; Lichtenstein, A.H.; Loria, C.M.; Millen, B.E.; et al. 2013 AHA/ACC guideline on lifestyle management to reduce cardiovascular risk: A report of the American College of Cardiology/American Heart Association Task Force on Practice Guidelines. Circulation 2014, 129 (Suppl. 2), S76-S99. [CrossRef]

12. U.S. Department of Health and Human Services and U.S. Department of Agriculture. 2015-2020 Dietary Guidelines for Americans, 8th ed.; U.S. Department of Health and Human Services and U.S. Department of Agriculture: Washington, DC, USA, 2015.

13. Molitch, M.E.; Adler, A.I.; Flyvbjerg, A.; Nelson, R.G.; So, W.Y.; Wanner, C.; Kasiske, B.L.; Wheeler, D.C.; de Zeeuw, D.; Mogensen, C.E. Diabetic kidney disease: A clinical update from Kidney Disease: Improving Global Outcomes. Kidney Int. 2015, 87, 20-30. [CrossRef] [PubMed]

14. Academy of Nutrition and Dietetics Evidence Analysis Library, 2015. Chronic Kidney Disease (CKD) Evidence-Based Nutrition Practice Guideline. 2010. USA. Available online: https:/ / www.andeal.org/topic.cfm? cat=3927 (accessed on 1 February 2019).

15. Higgins JPT GSe. Cochrane Handbook for Systematic Reviews of Interventions Version 5.1.0 [Updated March 2011]; The Cochrane Collaboration: London, UK, 2011.

16. Liberati, A.; Altman, D.G.; Tetzlaff, J.; Mulrow, C.; Gotzsche, P.C.; Ioannidis, J.P.; Clarke, M.; Devereaux, P.J.; Kleijnen, J.; Moher, D. The PRISMA statement for reporting systematic reviews and meta-analyses of studies that evaluate health care interventions: Explanation and elaboration. J. Clin. Epidemiol. 2009, 62, e1-e34. [CrossRef] [PubMed]

17. American Diabetes Association. 10. Microvascular Complications and Foot Care: Standards of Medical Care in Diabetes-2018. Diabetes Care 2018, 41 (Suppl. 1), S105-S118. [CrossRef] [PubMed]

18. Higgins, J.P.; Altman, D.G.; Gotzsche, P.C.; Juni, P.; Moher, D.; Oxman, A.D.; Savovic, J.; Schulz, K.F.; Weeks, L.; Sterne, J.A.; et al. The Cochrane Collaboration's tool for assessing risk of bias in randomised trials. BMJ 2011, 343, d5928. [CrossRef] [PubMed]

19. De Mello, V.D.; Zelmanovitz, T.; Perassolo, M.S.; Azevedo, M.J.; Gross, J.L. Withdrawal of red meat from the usual diet reduces albuminuria and improves serum fatty acid profile in type 2 diabetes patients with macroalbuminuria. Am. J. Clin. Nutr. 2006, 83, 1032-1038. [CrossRef] [PubMed]

20. Kontessis, P.A.; Bossinakou, I.; Sarika, L.; Iliopoulou, E.; Papantoniou, A.; Trevisan, R.; Roussi, D.; Stipsanelli, K.; Grigorakis, S.; Souvatzoglou, A. Renal, metabolic, and hormonal responses to proteins of different origin in normotensive, nonproteinuric type I diabetic patients. Diabetes Care 1995, 18, 1233. [CrossRef] [PubMed]

21. Jibani, M.M.; Bloodworth, L.L.; Foden, E.; Griffiths, K.D.; Galpin, O.P. Predominantly vegetarian diet in patients with incipient and early clinical diabetic nephropathy: Effects on albumin excretion rate and nutritional status. Diabet. Med. 1991, 8, 949-953. [CrossRef]

22. Dall'Alba, V.; Silva, F.M.; Antonio, J.P.; Steemburgo, T.; Royer, C.P.; Almeida, J.C.; Gross, J.L.; Azevedo, M.J. Improvement of the metabolic syndrome profile by soluble fibre-Guar gum-In patients with type 2 diabetes: A randomised clinical trial. Br. J. Nutr. 2013, 110, 1601-1610. [CrossRef]

23. Paula, T.P.; Viana, L.V.; Neto, A.T.; Leitao, C.B.; Gross, J.L.; Azevedo, M.J. Effects of the DASH Diet and Walking on Blood Pressure in Patients With Type 2 Diabetes and Uncontrolled Hypertension: A Randomized Controlled Trial. J. Clin. Hypertens. (Greenwich) 2015, 17, 895-901. [CrossRef]

24. Nicholson, A.S.; Sklar, M.; Barnard, N.D.; Gore, S.; Sullivan, R.; Browning, S. Toward improved management of NIDDM: A randomized, controlled, pilot intervention using a lowfat, vegetarian diet. Prev. Med. 1999, 29, 87-91. [CrossRef] 
25. Farhangi, M.A.; Javid, A.Z.; Dehghan, P. The effect of enriched chicory inulin on liver enzymes, calcium homeostasis and hematological parameters in patients with type 2 diabetes mellitus: A randomized placebo-controlled trial. Prim. Care Diabetes 2016, 10, 265-271. [CrossRef]

26. Maezawa, Y.; Takemoto, M.; Yokote, K. Cell biology of diabetic nephropathy: Roles of endothelial cells, tubulointerstitial cells and podocytes. J. Diabetes Investig. 2015, 6, 3-15. [CrossRef] [PubMed]

27. Fujii, H.; Iwase, M.; Ohkuma, T.; Ogata-Kaizu, S.; Ide, H.; Kikuchi, Y.; Idewaki, Y.; Joudai, T.; Hirakawa, Y.; Uchida, K.; et al. Impact of dietary fiber intake on glycemic control, cardiovascular risk factors and chronic kidney disease in Japanese patients with type 2 diabetes mellitus: The Fukuoka Diabetes Registry. Nutr. J. 2013, 12, 159. [CrossRef] [PubMed]

28. Post, R.E.; Mainous, A.G., 3rd; King, D.E.; Simpson, K.N. Dietary fiber for the treatment of type 2 diabetes mellitus: A meta-analysis. J. Am. Board Fam. Med. 2012, 25, 16-23. [CrossRef] [PubMed]

29. De Carvalho, C.M.; de Paula, T.P.; Viana, L.V.; Machado, V.M.; de Almeida, J.C.; Azevedo, M.J. Plasma glucose and insulin responses after consumption of breakfasts with different sources of soluble fiber in type 2 diabetes patients: A randomized crossover clinical trial. Am. J. Clin. Nutr. 2017, 106, 1238-1245. [CrossRef]

30. Showail, A.A.; Ghoraba, M. The association between glycemic control and microalbuminuria in Type 2 diabetes. Saudi J. Kidney Dis. Transplant. 2016, 27, 473-479. [CrossRef]

31. DCCT/EDIC Research Group. Effect of intensive diabetes treatment on albuminuria in type 1 diabetes: Long-term follow-up of the Diabetes Control and Complications Trial and Epidemiology of Diabetes Interventions and Complications study. Lancet Diabetes Endocrinol. 2014, 2, 793-800. [CrossRef]

32. Chen, W.Z.; Hung, C.C.; Wen, Y.W.; Ning, H.C.; Gau, B.R.; Huang, Y.Y. Effect of glycemic control on microalbuminuria development among type 2 diabetes with high-normal albuminuria. Ren. Fail. 2014, 36, 171-175. [CrossRef]

33. Metcalf, P.A.; Baker, J.R.; Scragg, R.K.; Dryson, E.; Scott, A.J.; Wild, C.J. Dietary nutrient intakes and slight albuminuria in people at least 40 years old. Clin. Chem. 1993, 39, 2191-2198.

34. Kondo, K.; Morino, K.; Nishio, Y.; Ishikado, A.; Arima, H.; Nakao, K.; Nakagawa, F.; Nikami, F.; Sekine, O.; Nemoto, K.I.; et al. Fiber-rich diet with brown rice improves endothelial function in type 2 diabetes mellitus: A randomized controlled trial. PLoS ONE 2017, 12, e0179869. [CrossRef]

35. Chiavaroli, L.; Mirrahimi, A.; Sievenpiper, J.L.; Jenkins, D.J.; Darling, P.B. Dietary fiber effects in chronic kidney disease: A systematic review and meta-analysis of controlled feeding trials. Eur. J. Clin. Nutr. 2015, 69, 761-768. [CrossRef] [PubMed]

36. Salmean, Y.A.; Segal, M.S.; Langkamp-Henken, B.; Canales, M.T.; Zello, G.A.; Dahl, W.J. Foods with added fiber lower serum creatinine levels in patients with chronic kidney disease. J. Ren. Nutr. 2013, 23, e29-e32. [CrossRef] [PubMed]

37. Mirmiran, P.; Yuzbashian, E.; Asghari, G.; Sarverzadeh, S.; Azizi, F. Dietary fibre intake in relation to the risk of incident chronic kidney disease. Br. J. Nutr. 2018, 119, 479-485. [CrossRef] [PubMed]

38. Kelly, J.T.; Palmer, S.C.; Wai, S.N.; Ruospo, M.; Carrero, J.J.; Campbell, K.L.; Strippoli, G.F. Healthy Dietary Patterns and Risk of Mortality and ESRD in CKD: A Meta-Analysis of Cohort Studies. Clin. J. Am. Soc. Nephrol. 2017, 12, 272-279. [CrossRef] [PubMed]

39. Gluba-Brzozka, A.; Franczyk, B.; Rysz, J. Vegetarian Diet in Chronic Kidney Disease-A Friend or Foe. Nutrients 2017, 9, 374. [CrossRef] [PubMed]

40. Melina, V.; Craig, W.; Levin, S. Position of the Academy of Nutrition and Dietetics: Vegetarian Diets. J. Acad. Nutr. Diet. 2016, 116, 1970-1980. [CrossRef] [PubMed]

41. Lohsiriwat, S. Protein Diet and Estimated Glomerular Filtration Rate. Open J. Nephrol. 2013, 3, 97-100. [CrossRef]

42. Barai, S.; Gambhir, S.; Prasad, N.; Sharma, R.K.; Ora, M.; Kumar, A.; Gupta, A.; Parasar, D.S.; Suneetha, B. Levels of GFR and protein-induced hyperfiltration in kidney donors: A single-center experience in India. Am. J. Kidney Dis. 2008, 51, 407-414. [CrossRef]

43. Moorthi, R.N.; Vorland, C.J.; Hill Gallant, K.M. Diet and Diabetic Kidney Disease: Plant Versus Animal Protein. Curr. Diabetes Rep. 2017, 17, 15. [CrossRef]

44. Kaysen, G.A.; Odabaei, G. Dietary protein restriction and preservation of kidney function in chronic kidney disease. Blood Purif. 2013, 35, 22-25. [CrossRef] 
45. Jacobs, D.R., Jr.; Gross, M.D.; Steffen, L.; Steffes, M.W.; Yu, X.; Svetkey, L.P.; Appel, L.J.; Vollmer, W.M.; Bray, G.A.; Moore, T.; et al. The effects of dietary patterns on urinary albumin excretion: Results of the Dietary Approaches to Stop Hypertension (DASH) Trial. Am. J. Kidney Dis. 2009, 53, 638-646. [CrossRef] [PubMed]

46. Lin, J.; Fung, T.T.; Hu, F.B.; Curhan, G.C. Association of dietary patterns with albuminuria and kidney function decline in older white women: A subgroup analysis from the Nurses' Health Study. Am. J. Kidney Dis. 2011, 57, 245-254. [CrossRef] [PubMed]

47. Rebholz, C.M.; Crews, D.C.; Grams, M.E.; Steffen, L.M.; Levey, A.S.; Miller, E.R., 3rd; Appel, L.J.; Coresh, J. DASH (Dietary Approaches to Stop Hypertension) Diet and Risk of Subsequent Kidney Disease. Am. J. Kidney Dis. 2016, 68, 853-861. [CrossRef] [PubMed]

48. Asghari, G.; Farhadnejad, H.; Mirmiran, P.; Dizavi, A.; Yuzbashian, E.; Azizi, F. Adherence to the Mediterranean diet is associated with reduced risk of incident chronic kidney diseases among Tehranian adults. Hypertens. Res. 2017, 40, 96-102. [CrossRef] [PubMed]

49. Diaz-Lopez, A.; Babio, N.; Martinez-Gonzalez, M.A.; Corella, D.; Amor, A.J.; Fito, M.; Estruch, R.; Aros, F.; Gomez-Gracia, E.; Fiol, M.; et al. Mediterranean Diet, Retinopathy, Nephropathy, and Microvascular Diabetes Complications: A Post Hoc Analysis of a Randomized Trial. Diabetes Care 2015, 38, 2134-2141. [CrossRef] [PubMed]

50. Diaz-Lopez, A.; Bullo, M.; Martinez-Gonzalez, M.A.; Guasch-Ferre, M.; Ros, E.; Basora, J.; Covas, M.I.; del Carmen Lopez-Sabater, M.; Salas-Salvado, J.; Investigators, P.R.S. Effects of Mediterranean diets on kidney function: A report from the PREDIMED trial. Am. J. Kidney Dis. 2012, 60, 380-389. [CrossRef] [PubMed]

51. Dahl, W.J.; Stewart, M.L. Position of the Academy of Nutrition and Dietetics: Health Implications of Dietary Fiber. J. Acad. Nutr. Diet. 2015, 115, 1861-1870. [CrossRef]

52. EFSA Panel on Dietetic Products, Nutrition, and Allergies (NDA). Scientific Opinion on Dietary Reference Values for carbohydrates and dietary fibre. EFSA J. 2010, 8, 1462.

53. Medina-Remon, A.; Kirwan, R.; Lamuela-Raventos, R.M.; Estruch, R. Dietary patterns and the risk of obesity, type 2 diabetes mellitus, cardiovascular diseases, asthma, and neurodegenerative diseases. Crit. Rev. Food Sci. Nutr. 2018, 58, 262-296. [CrossRef]

54. Krishnamurthy, V.M.; Wei, G.; Baird, B.C.; Murtaugh, M.; Chonchol, M.B.; Raphael, K.L.; Greene, T.; Beddhu, S. High dietary fiber intake is associated with decreased inflammation and all-cause mortality in patients with chronic kidney disease. Kidney Int. 2012, 81, 300-306. [CrossRef] 